\title{
Technè
}

La science au service de l'histoire de l'art et de la

préservation des biens culturels

$43 \mid 2016$

Une Europe de la recherche en sciences du patrimoine

\section{Discerning differences: Ion beam analysis of ancient faience from Naukratis and Rhodes}

Discerner les différences : l'analyse par faisceaux d'ions de faïences antiques de

Naucratis et Rhodes

Andrew Meek, Anne Bouquillon, Patrice Lehuédé, Aurélia Masson, Alexandra Villing, Geneviève Pierrat-Bonnefois et Virginia Webb

\section{OpenEdition}

Journals

Édition électronique

URL : http://journals.openedition.org/techne/804

DOI : $10.4000 /$ techne.804

ISSN : 2534-5168

Éditeur

C2RMF

Édition imprimée

Date de publication : 1 août 2016

Pagination : $94-101$

ISBN : 978-2-7118-6338-9

ISSN : 1254-7867

Référence électronique

Andrew Meek, Anne Bouquillon, Patrice Lehuédé, Aurélia Masson, Alexandra Villing, Geneviève PierratBonnefois et Virginia Webb, « Discerning differences: Ion beam analysis of ancient faience from

Naukratis and Rhodes », Technè [En ligne], 43 | 2016, mis en ligne le 19 décembre 2019, consulté le 24 juillet 2020. URL : http://journals.openedition.org/techne/804 ; DOI : https://doi.org/10.4000/techne. 804

\section{(c) $\mathbb{\Theta \Theta}$}

La revue Technè. La science au service de l'histoire de l'art et de la préservation des biens culturels est mise à disposition selon les termes de la Licence Creative Commons Attribution - Pas d'Utilisation Commerciale - Pas de Modification 4.0 International. 


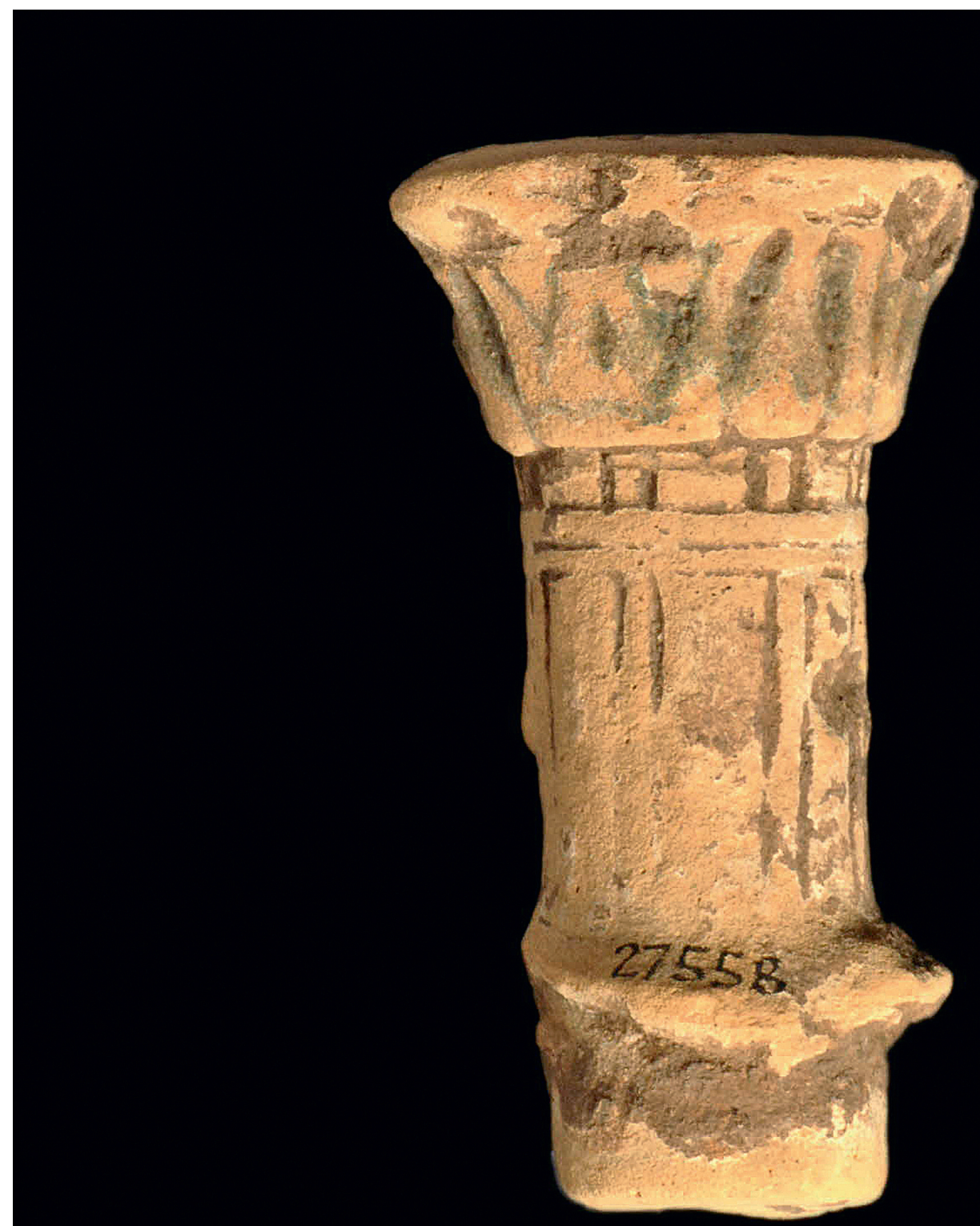

Fig. 1. New Year's flask neck BM 1885,1101.29. @ Trustees of the British Museum. 
Andrew Meek

Anne Bouquillon

Patrice Lehuédé

Aurélia Masson

Alexandra Villing

Geneviève Pierrat-Bonnefois

Virginia Webb

\section{Discerning differences: Ion beam analysis of ancient faience from Naukratis and Rhodes}

Discerner les différences : l'analyse par faisceaux d'ions de faïences antiques de Naucratis et Rhodes
Abstract. Faience technology was known in Egypt since the Predynastic Period and practiced for a period also in Bronze Age Greece, but, having been lost, was reintroduced to the Greek world only in the first half of the first millennium BC. The Greek island of Rhodes and the Greek-Egyptian trade harbour of Naukratis in the Nile Delta are suspected to be key centres of early Greek-style faience production, exporting amulets and vessels across the Mediterranean region. Yet the nature and scale of their production and their role in technology transfer, vis-à-vis Egyptian and Levantine/Phoenician production, remain little understood. The main aim of this study was to discover whether it is possible to define chemical characteristics for the faience produced and found at Naukratis, and to use this data to differentiate between artefacts produced here and elsewhere.

A programme of ion beam (PIXE and PIGE) analysis was conducted under the CHARISMA transnational access scheme, known to be a suitable tool for studying ancient vitreous artefacts as it provides a non-destructive means of obtaining precise and accurate quantitative compositional data. Both the internal body of damaged objects as well as the outer glaze layer were analysed, of which only the latter are discussed here. The results of this study indicate that the faience found at both Naukratis and on Rhodes is compositionally similar. However, some small differences were found in the raw materials used in its production which may help us to better characterise the production of different faience manufacturing centres.

Keywords. Faience, provenance, Egypt, Rhodes, PIXE, archaeometry.
Résumé. La technique de la faïence, connue en Égypte depuis la période prédynastique et utilisée également pendant un certain temps en Grèce à l'âge du Bronze, s'est perdue ensuite. Elle ne fut réintroduite dans le monde grec que vers la première moitié du $I^{e r}$ millénaire av. J.-C. On pense que l'île grecque de Rhodes et le port marchand gréco-égyptien de Naucratis dans le delta du Nil furent de grands foyers de production de faïences, exportant des amulettes et des vases dans tout le pourtour méditerranéen. Cependant, la nature et l'ampleur de leur production restent mal connues, de même que leur rôle dans la diffusion des techniques de fabrication en Égypte et au Levant/Phénicie. Cette recherche avait pour principal objectif de savoir sil était possible de déterminer les caractéristiques chimiques des faïences fabriquées et découvertes à Naucratis, afin de mieux discerner les différences entre les objets produits surce site et ailleurs.

Nous avons pu conduire des analyses par faisceaux d'ions (méthodes PIXE et PIGE) dans le cadre du programme européen CHARISMA d'accès transnational, offrant un outil adapté à l'étude des objets antiques vitrifiés, car c'est un moyen non-destructeur de recueillir des données quantitatives précises et fiables sur la composition des matériaux. Nous avons analysé aussi bien la pâte, à l'intérieur d'objets abîmés, que la glaçure extérieure, et c'est cette dernière qui est décrite ici. Les résultats de notre étude font apparaître une composition similaire pour les faïences découvertes à Naucratis et à Rhodes. Quelques petites variations découvertes dans les matières premières employées pourraient faciliter la caractérisation des faïences fabriquées dans les différents foyers de production.

Mots-clés. Faïence, provenance, Égypte, Rhodes, méthode PIXE, archéométrie.

\section{Introduction}

The city and trading port of Naukratis in Egypt, inhabited by both Greeks and Egyptians, was an important faience production centre, especially between 600 and 550 BC. Scarabs and other amulets manufactured in the so-called "Scarab
Factory", excavated by W.M.F. Petrie in 1885, were exported throughout the Mediterranean world ${ }^{1}$. It is likely that other faience products were also made in Naukratis and distributed widely, for example figurines of musicians which can be dated from separate evidence down to $550 \mathrm{BC}^{2}$ and New Year's flasks $^{3}$. In addition to some typical Egyptian motifs, many

Andrew Meek, scientist, Department of Scientific Research, The British Museum (ameek@britishmuseum.org). Anne Bouquillon, ingénieur de recherche, C2RMF (anne.bouquillon@culture.gouv.fr). Patrice Lehuédé, chercheur bénévole, C2RMF (patrice.lehuede@culture.gouv.fr). Aurélia Masson, curator, Department of Ancient Egypt and Sudan, The British Museum (amasson-berghoff@britishmuseum.org). Alexandra Villing, curator, Department of Greece and Rome, The British Museum (avilling@britishmuseum.org). Geneviève Pierrat-Bonnefois, Conservateur en chef, département des Antiquités égyptiennes, musée du Louvre (genevieve.pierrat@louvre.fr). Virginia Webb, independent researcher, (webbvirginia25@gmail.com). 
scarabs and scaraboids feature a hybrid Greek-Egyptian or Near Eastern iconography. This has raised the question of the ethnic identity of the craftsmen involved in this factory: local Egyptians, Greek settlers or Phoenician craftsmen? Although faience technology was already known in Egypt since the Predynastic Period and had existed in Bronze Age Crete and possibly also Mycenaean Greece, it had disappeared along with those cultures at the end of the Bronze Age and it is only during the first half of the first millennium BC that the technology was reintroduced to the Greek world. The Greek island of Rhodes is considered to be one of the earliest centres producing faience at least partly in a Greek style, followed later by Naukratis. The routes and agents of this technology transfer remain little understood, in particular the respective role played by Egypt and the Levant/Phoenicia, which both have strong traditions of local faience production $^{4}$.

The collaborative study between the Musée du Louvre, the Centre de Recherche et de Restauration des Musées de France (C2RMF), the British Museum and the Ashmolean Museum was established as part of a wider programme coordinated by Geneviève Pierrat-Bonnefois. This project aims to shed new light on the production of faience and trade networks, cultural contact and technology transfer in the ancient Mediterranean and Egypt during the first half of the 1st millennium BC.

\section{Objects analysed}

A large and representative number of faience objects from Naukratis and Rhodes were selected for analysis, comprising twenty-six objects from Naukratis, seven from Kamiros on Rhodes and one of unknown origin which was excavated at either Naukratis or Kamiros in the British Museum, one from Naukratis in the Ashmolean Museum and eight from Naukratis and one from Kamiros in the Musée du Louvre. They included faience vessels, scarabs, scaraboids and figurines, as well as elements related to the manufacture of these objects such as wasters. The selected figurines comprised all the main categories: musicians (such as lyre, flute or drum players), naked women and animals, mainly falcon, ram and lion. A few Egyptian style amulets were included in the group, such as Pataikos amulets and Bes heads.

\section{Methodology}

PIXE analysis was performed with the AGLAE 2 MV ion accelerator of the C2RMF located in the basement of the Louvre $^{5}$. The ion beams are extracted to the atmosphere through a thin window. PIXE is performed with $3 \mathrm{MeV}$ protons. A helium flow is maintained on the beam paths (particles, $\mathrm{X}$-rays) to minimize energy losses and scattering. PIXE is used to obtain an average chemical composition of materials assumed to be homogeneous in the volume covered by the X-ray emission. The GUPIX code was used to determine major and trace oxide/element concentrations.

\section{Results}

\section{Introduction}

Compositional data was acquired for 44 objects (see Table 1). More than one point/area on objects with multiple colours of glaze was analysed, resulting in a dataset of 57 analyses. These analyses were carried out on the internal body of damaged objects as well as the outer glaze layer. Only the results for glazes will be reported in this article.

As with any form of surface analysis, there are some issues with the data. Faience, like most vitreous materials, deteriorates over time and the composition of the surface is often not representative of the original composition of the glaze. This process normally results in a loss of alkali components (soda $\left[\mathrm{Na}_{2} \mathrm{O}\right]$ and potash $\left.\left[\mathrm{K}_{2} \mathrm{O}\right]\right)^{6}$. It can also cause alterations in the colour of the glaze ${ }^{7}$.

In the case of the objects analysed here, there is also a problem with contamination. The majority of the analyses have elevated levels of calcium, sulphur, phosphorus or chlorine when compared with previously published analyses ${ }^{8}$. This suggests that the objects have undergone a process of post-depositional alteration and are contaminated with sulphates, carbonates, chlorides and phosphates ${ }^{9}$. This will not only cause issues with the calcium, sulphur, phosphorus or chlorine levels reported in this work, but also the levels of all other components will be reported below their actual amounts present below this contaminated surface layer. Where levels of these components are above $5 \mathrm{wt} \%$, the data for these area analyses should be considered semi-quantitative (see Table 1).

Despite these problems, the use of non-destructive PIXE analysis at AGLAE was indispensable, since the very small size of many of the objects essentially made sampling impossible. The results set out below moreover confirm the method's efficacy.

On first study of the results, the glazes of the faience objects from Naukratis and Kamiros appear to have very similar chemical characteristics. Oxides which are components of the basic raw materials (such as potash and alumina, see fig. 2) were found to be variable at both sites, but there was a high degree of similarity between sites.

\section{Colours}

\section{Yellow}

No yellow glazed objects from Rhodes were selected for analysis during this project. The yellow glazes analysed on objects from Naukratis were all found to contain significant levels of lead $(\mathrm{Pb})$ and antimony $(\mathrm{Sb})$. The presence of lead antimonate 


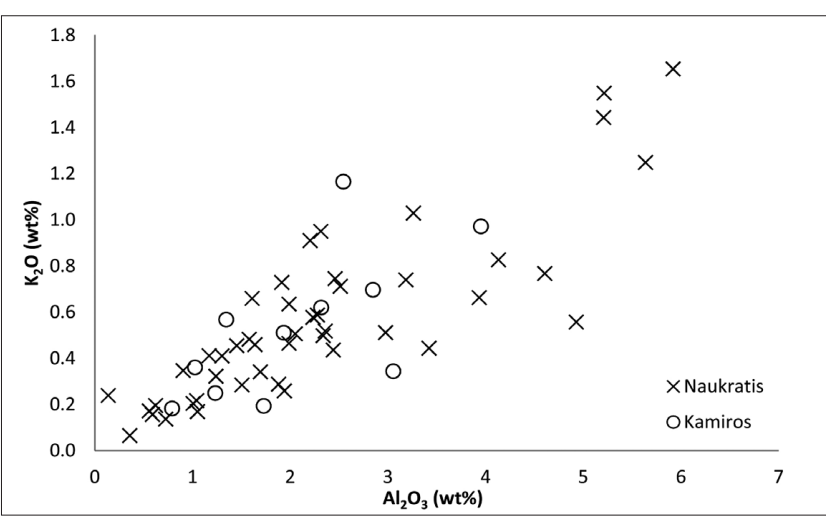

Fig. 2. Plot illustrating the relationship between potassium oxide $\left(\mathrm{K}_{2} \mathrm{O}\right)$ and aluminium oxide $\left(\mathrm{Al}_{2} \mathrm{O}_{3}\right)$ levels in the glazes of the faience objects analysed from Naukratis and Kamiros.

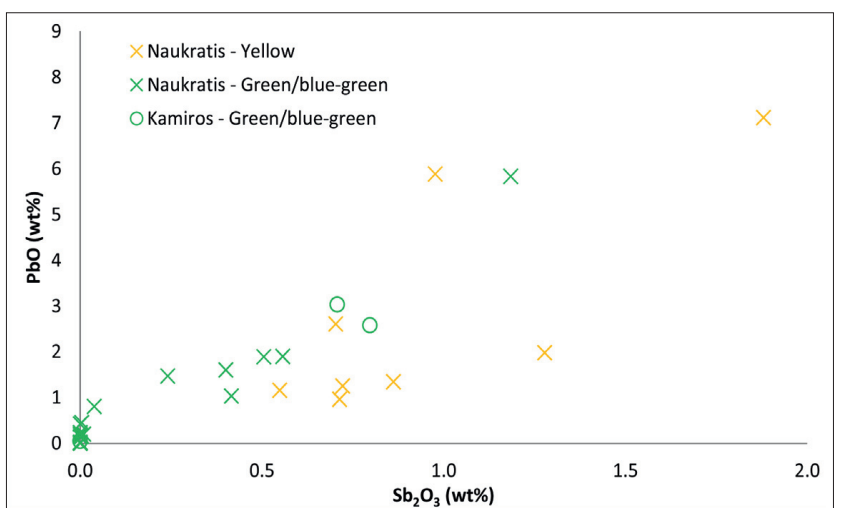

Fig. 3. Plot illustrating the relationship between lead oxide ( $\mathrm{PbO})$ and antimony oxide $\left(\mathrm{Sb}_{2} \mathrm{O}_{3}\right)$ levels in the yellow and green/bluegreen glazes of the faience objects analysed from Naukratis and Kamiros. The data for one yellow object (scarab, BM 1886,0401.1625) is not included in this plot. This object has exceptionally high antimony oxide levels $\left(>10 \mathrm{wt} \% \mathrm{Sb}_{2} \mathrm{O}_{3}\right)$ and is discussed above.
$\left(\mathrm{Pb}_{2} \mathrm{Sb}_{2} \mathrm{O}_{7}\right)$ crystals within a glass or glaze imparts opacity and a yellow colouration. There is a weak correlation $(\mathrm{PbO} /$ $\mathrm{Sb}_{2} \mathrm{O}_{3}$ ratio has a fairly small range, between 1.5 and 3.5) between the quantities of lead and antimony present in these objects, apart from one scarab (BM 1886,0401.1625), suggesting that they may have been added together as parts of a single raw material. However, further analysis would be needed to confirm this. The one yellow scarab which does not fit this pattern (BM 1886,0401.1625) contains exceptionally high antimony oxide levels and has a $\mathrm{PbO} / \mathrm{Sb}_{2} \mathrm{O}_{3}$ ratio of 0.8 . This object was probably produced using a different recipe and/ or antimony-rich raw material.

A further number of the yellow scarabs have iron and tin levels which varied significantly from the other yellow objects. One of the yellow scarabs analysed was found to contain high iron levels (BM 1886,0401.1608) and three others contain a significant level of tin oxide (Louvre E 8056 bis 12, Louvre E 8056 bis 5 and BM 1886,0401.1625) (Table 1). The presence of tin and iron in lead-antimonate particles is common and is probably linked to the heterogeneity of the raw materials used $^{10}$.

\section{Green/Blue-green}

The green/blue-green glazes are the most common in the analysed assemblage. This colour is sometimes homogenous on the best preserved artefacts, but often only coloured spots remain on a powdery faience body (see fig. 1). Differences in the results of the chemical analyses have allowed us to propose two main compositional types for the objects from Naukratis.

The first type is characterised by glazes which contain significant levels of antimony and lead. The colour of these objects is produced by mixing copper oxides, and associated varying levels of iron oxide, with lead antimonate. The hue is a function of the relative quantities of each component.
This group consists of four objects from the British Museum (three scarabs BM 1886,0401.1621, 1886,0401.1626 and 1886,0401.1660, one New Year's flask BM 1886,0401.1589) and two scarabs from the Louvre collections (Louvre E8056 bis 9 and 11). One further object with very low antimony oxide levels (New Year's flask, BM 1885,1101.29, fig. 1) may be included in this group. This low antimony, potentially correlated leadantimony object is also the only object in the entire assemblage which contains high levels of tin (c. $2 \mathrm{wt} \% \mathrm{SnO}_{2}$ ).

As with the yellow glazes, the correlation between lead and antimony seen in a number of the results suggests that they may also have been added as a single ingredient to these green/blue-green objects. Objects of these colours previously analysed by Kaczmarczyk and Hedges ${ }^{11}$ also show a correlation between lead and antimony. The fact that this correlation was also found by other researchers strongly suggests that a single ingredient may be responsible for the presence of these components in a significant number of the green/blue-green coloured objects.

The second group consists of 10 objects. Lead is present as a minor element (average $0.2 \mathrm{wt} \% \mathrm{PbO}$ ) and very little, if any, antimony was detected in these objects (fig. 3). Their colour is only caused by the presence of copper and/or iron oxides. The presence of copper and lack of lead antimonate in these glazes is likely to have given them a turquoise appearance when produced. The colour could have become greener through weathering processes during burial or, as for BM $1886,0401.1641$ (couchant lion) where iron was present in significant quantities, a green colouration would have always been present.

The three green/blue-green glazed objects from Kamiros have varying lead and antimony levels and also fall into two groups (fig. 2, Table 1). Two objects have fairly similar lead and antimony levels (c. $0.75 \mathrm{wt} \% \mathrm{Sb}_{2} \mathrm{O}_{5}$ and $\left.3 \mathrm{wt} \% \mathrm{PbO}\right)$ and are very similar in appearance (scarabs BM 1861,0425.12 and 1861,0425.13). They are relatively free from weathering and 
have the strongest blue-green colour of any of the objects analysed in this study. These two objects share extremely similar chemical characteristics and were therefore made from an almost identical set of ingredients and recipe. The third object has a different form (ram, BM 1861,1024.22) and contains very little lead or antimony, similar to the majority of objects analysed from Naukratis.

\section{Blue}

Four objects are characterised by a more or less obvious blue colour. They all contain significant levels of cobalt $(>0.07 \mathrm{wt} \%$ $\mathrm{CoO})$. Three were excavated in Kamiros; two very similar scaraboids (BM 1861,0425.20 and 1861,0425.21) and another scarab (Louvre E 3899) (fig. 4a-c). In these objects, the presence of cobalt is associated with elevated levels of other elements (iron, nickel, manganese, aluminium and magnesium). This association is common in deep-blue glasses and glazes coloured using cobaltiferous alums from the Western Oases of Egypt ${ }^{12}$. The variations in cobalt concentrations are probably due to different mixtures of colorants, rather than changes in the cobalt source used. Copper also seems to have been added separately, sometimes in very high quantities, to alter the hue and obtain the brightest blue colour.

The findspot of the fourth object containing cobalt (falcon waster, BM 2013,5012.11, fig. 4d) is uncertain, but it is known to come from either Naukratis or Kamiros. This object contains very low levels of nickel along with cobalt, and this may have been an impurity added along with the cobalt source used in its production, similar to that found in the three other blue objects from Kamiros.

\section{Dark-coloured decoration}

The dark-coloured decoration (often described as black or brown) on many of the objects is produced by the addition of large quantities of manganese, normally in combination with iron. Two main compositional types can be proposed for glazes of this colour.

The first group includes the largest number of objects, 10 pieces, which are all from Naukratis. In this group, the black glazes are coloured with a mixture of manganese and iron. In a few cases, barium is associated with manganese. This suggests that different manganese-containing ores have been used. Where significant levels of barium were detected, romanechite or psilomelane can be proposed as the manganese source. Where very little or no barium was detected, pyrolusite-rich deposits were probably used. Similar differences have already been observed by Kaczmarczyk and Hedges $^{13}$.

The second group can be very clearly differentiated from the first. All of the objects in this group contain low levels of cobalt and nickel, as well as manganese and iron (fig. 5). This may be an intentional addition that plays a role in the final appearance of the glaze and enhances the dark colour. Such a mixture is detected in the dark glazes of the three objects analysed from Kamiros and only on one (a musician figure, BM 1886,0401.1330) found at Naukratis. This recipe seems to be strongly linked to Kamiros. Indeed, previous analyses of black glazes on four figurines from Kamiros (Louvre NIII 2407, AM 403, AM 404 and MN 2416) show the presence of cobalt and nickel, associated with manganese ${ }^{14}$.

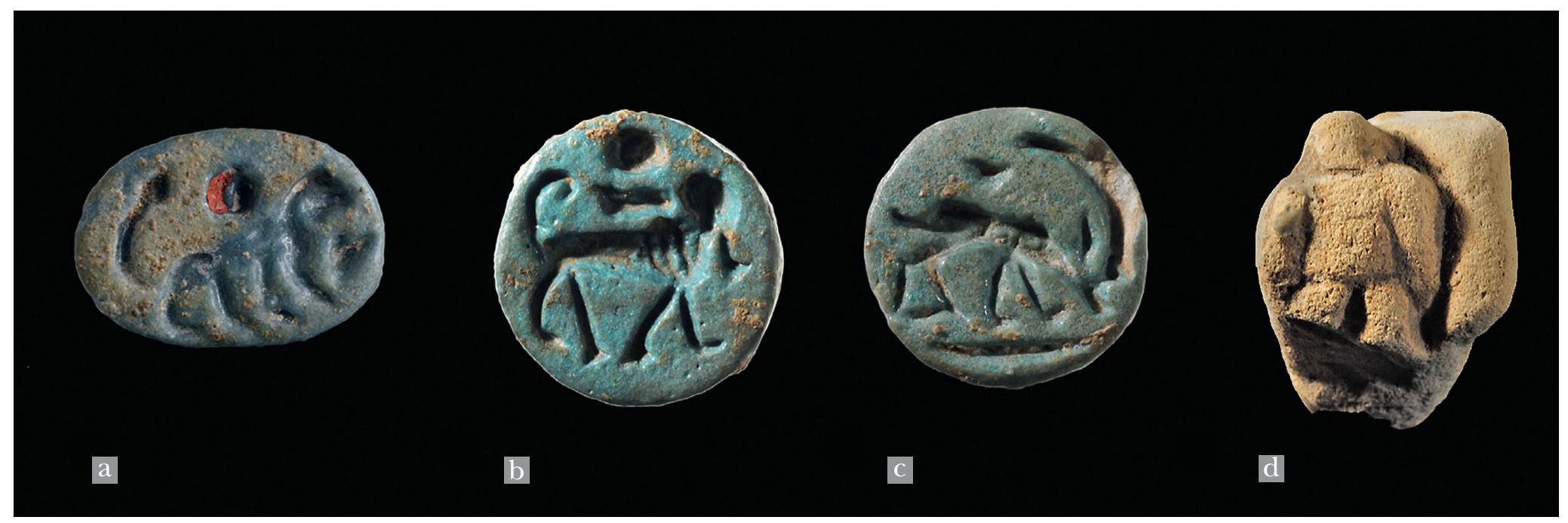

Fig. 4. Cobalt-containing blue glazed objects:

a) Scarab with image of a lion (Louvre E3899 width $0.88 \mathrm{~cm}$ ) (C) Musée du Louvre/Christian

Décamps. b) Scaraboid with image of sphinx (BM 1861,0425.20 width $1.27 \mathrm{~cm}$ ), c) Scaraboid with image of wild goat or ibex (BM 1861,0425.21 width $1.27 \mathrm{~cm}$ ), d) Falcon waster

(BM 2013,5012.11 height $2.20 \mathrm{~cm}$ ). (C) Trustees of the British Museum. 


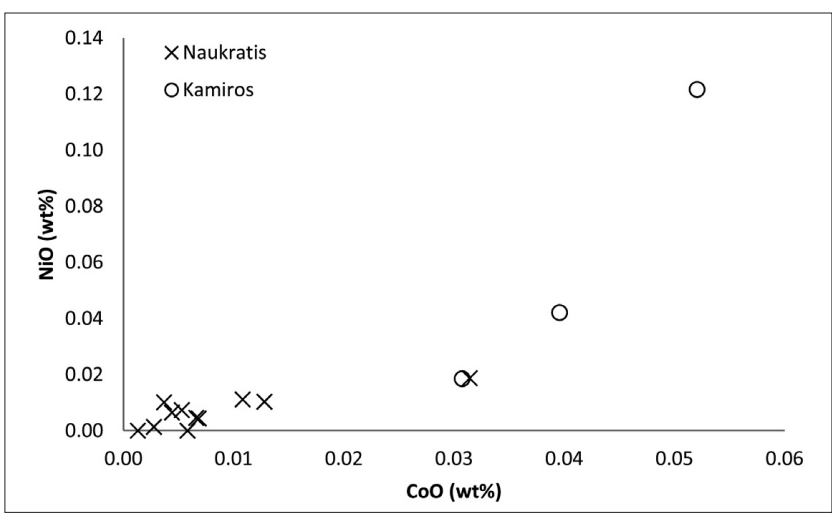

Fig. 5. Plot illustrating the relationship between nickel oxide (NiO) and cobalt oxide $(\mathrm{CoO})$ levels in the dark-coloured glazes of the faience objects analysed from Naukratis and Kamiros.

\section{Preliminary conclusions and future work}

The preliminary study of the data has revealed many interesting similarities and differences with, and between, the chemical composition of faience objects from Naukratis and Rhodes. Many of these patterns correspond with those previously found in the analysis of other faience items from the collections of the Louvre ${ }^{15}$.

It is clear that there were similarities in the raw materials and recipes used to produce the faience found at both of these sites. However, some differences can be seen in the materials used to colour these objects. At this stage, the differences and correlations in lead and antimony levels in yellow and green/blue-green glazes, and identification of differences in the use of cobalt to produce the dark-coloured glazes, seem to provide the greatest hope in showing differences between the two production areas.
The correlation found between lead and antimony levels in some yellow and green/blue-green scarabs and New Year's flasks from Naukratis suggests that a single material containing both of these ingredients was used in their production. In the future, this may provide a means of characterising some of the faience from Naukratis. A comparison with Rhodian faience (small figurines and vases, but no scarabs or ram amulets) found in excavations performed by Salzmann and Biliotti at Kamiros show similar trends for green/bluegreen faience. The picture is not so clear for yellow faience, as the assemblage from the British Museum analysed in the present study does not include any yellow faience object from Rhodes.

The results for blue and dark-coloured faience items suggest that a nickel-containing cobalt source may have been used in their production at Rhodes, and not at Naukratis. Further analysis of a greater number of objects from both sites will be necessary to confirm this tentative pattern. If it can indeed be confirmed, it has the potential to be used as a provenancing tool.

It must also be borne in mind that production in Naukratis was confined to a shorter period than production on Rhodes, which ranged from 650 through to $525 \mathrm{BC}$. Further analysis and rigorous comparison with previously published studies of ancient faience production ${ }^{16}$ will be necessary before strong conclusions can be drawn.

\section{Acknowledgements}

AGLAE beam time was made possible under the FIXLAB transnational access programme of the CHARISMA project. Financial support by the Access to Research Infrastructures activity in the 7th Framework Programme of the EU (Grant Agreement n. 228330) and the help of the AGLAE team is gratefully acknowledged.
Notes

1. Gorton, 1996. Masson, forthcoming. 2. Webb, 2013-2015a.; Webb, 2013 $2015 b$.

3. Masson, 2013-2015.

4. Pierrat-Bonnefois, Bouquillon and Coulié, 2014; Caubet and Pierrat-Bonnefois, 2005; Busz and Gercke, 1999.

5. Technical information about the equipment and illustrations of its use can be found in: Salomon, Dran, Guillou, Moignard, Pichon, Walter and Mathis, 2008.

6. Newton and Davison, 1989, p. 136

7. Tite, Maniatis, Kavoussanaki, Panagiotaki, Shortland and Kirk, 2009

8. See: Tite, Freestone and Bimson, 1983; Tite, Freestone and Bimson, 1987; Tite and Shortland, 2003; Foster and Kaczmarczyk, 1982.

9. Pollard and Heron, 2008, p. 126-128; Strahan, 1991.

10. Duran, Castaing, Lehuédé and Bouquillon, 2012.
11. Kaczmarczyk and Hedges, 1983

12. Shortland, Tite and Ewart, 2006 ; Kaczmarczyk and Hedges, 1983.

13. Kaczmarczyk and Hedges, 1983

14. Pierrat-Bonnefois, Becq, Bouquillon and Lehuédé, 2015.

15. Pierrat-Bonnefois, Becq, Bouquillon and Lehuédé, 2015.

16. See: Tite, Freestone and Bimson, 1983; Tite, Freestone and Bimson, 1987; Tite, and Shortland, 2003; Foster and Kaczmarczyk, 1982; Pierrat-Bonnefois, Becq, Bouquillon and Lehuédé, 2015.

\section{Bibliography}

Busz R., Gercke P. (eds), 1999, Türkis und Azur: Quarzkeramik in Orient und Okzident, Wolfratshausen.

Caubet A., Pierrat-Bonnefois G. (eds), 2005 , Faïence de l'Antiquité. De l'Égypte à l'Iran, Paris.
Duran A., Castaing J., Lehuédé P., Bouquillon A., 2012, « Les pigments jaunes des glaçures de l'atelier des Della Robbia ", in Bouquillon A., Bormand M., Zucchiatti A. (eds), Della Robbia, dieci anni di studi, Geneva, 44-49.

Foster K. P., Kaczmarczyk A. 1982, "X-ray Fluorescence Analysis of Some Minoan Faience", Archaeometry 24, p. 143-157.

Gorton A. F., 1996, Egyptian and Egyptianising Scarabs. A Typology of Steatite, Faience, and Paste Scarabs from Punic and Other Mediterranean Sites, Oxford.

Kaczmarczyk A., Hedges R.E.M., 1983, Ancient Egyptian Faience, Warminster.

Masson A. (forthcoming), "Scarabs, scaraboids and amulets" in Villing A., Bergeron M., Bourogiannis G., Johnston A., Leclère F., Masson A., Thomas R., Naukratis: Greeks in Egypt, British Museum Online Research Catalogue. 
Table 1. PIXE-PIGE results for all glaze areas analysed from Naukratis and Kamiros (in bold) organised by glaze colour. Results are normalised to $100 \%$. Where the original colour is difficult to define, the compositional characteristics have been used to assign a colour to the object and a '?' used to note this. Where $\mathrm{P}_{2} \mathrm{O}_{5}, \mathrm{SO}_{3}, \mathrm{Cl}$ and $\mathrm{CaO}$ values are higher than $5 \mathrm{wt} \%$ results for these objects should be considered semi-quantitative.

\begin{tabular}{|c|c|c|c|c|c|c|c|c|}
\hline Site & Objects & Object type & Glaze colour & $\mathrm{Na}_{2} \mathrm{O}$ & $\mathrm{MgO}$ & $\mathrm{Al}_{2} \mathrm{O}_{3}$ & $\mathrm{SiO}_{2}$ & $\mathrm{P}_{2} \mathrm{O}_{5}$ \\
\hline Kamiros & 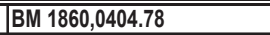 & Flute player & Colourless & 0.51 & 0.50 & 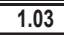 & 994.63 & 0.17 \\
\hline Kamiros & BM $1864,1007.960$ & Bull & Colourless & 0.46 & 0.48 & 1.35 & 94.58 & 0.12 \\
\hline Naukratis & BM 1886,0401.1326 & Lion & Colourless & 0.49 & 0.48 & 1.51 & 79.10 & 0.21 \\
\hline Naukratis & BM 1886,0401.1395 & Naked female & Colourless & 0.46 & 0.67 & 1.64 & 79.54 & 0.23 \\
\hline Naukratis & BM 1886,0401.1330 & Musician & Colourless & 0.77 & 0.87 & 2.23 & 83.31 & 0.59 \\
\hline Naukratis & BM 1886,0401.1331 & Ram & Colourless & 0.35 & 0.18 & 0.56 & 93.17 & 0.10 \\
\hline Naukratis & BM 1886,0401.1332 & Falcon & Colourless & 1.23 & 0.95 & 2.46 & 77.18 & 0.88 \\
\hline Naukratis & BM 1886,0401.1586 & Hieracosphinx & Colourless & 0.53 & 0.67 & 2.05 & 85.95 & 0.34 \\
\hline Naukratis & BM 1886,1005.16 & Harpokrates & Colourless & 0.36 & 0.73 & 3.93 & 83.05 & 0.68 \\
\hline Naukratis & BM 1886,0401.1584 & Pataikos & Colourless & 0.71 & 0.78 & 4.13 & 86.00 & 0.73 \\
\hline Kamiros & BM $1860,0404.78$ & Flute player & Dark & 0.32 & 0.33 & 0.79 & 90.63 & 0.10 \\
\hline Kamiros & BM $1864,1007.960$ & Bull & Dark & 0.40 & 0.35 & 2.54 & 86.97 & 0.13 \\
\hline Kamiros & BM 1861,1024.22 & Ram & Dark & 1.21 & 1.00 & 3.95 & 76.81 & 0.54 \\
\hline Naukratis & BM $1886,0401.1326$ & Lion & Dark & 0.93 & 0.38 & 2.34 & 86.94 & 0.23 \\
\hline Naukratis & BM 1886,0401.1395 & Naked female & Dark & 0.80 & 0.41 & 1.61 & 80.92 & 0.26 \\
\hline Naukratis & BM 1886,0401.1332 & Falcon & Dark & 2.08 & 0.81 & 5.21 & 62.24 & 0.42 \\
\hline Naukratis & BM 1886,0401.1586 & Hieracosphinx & Dark & 0.60 & 0.36 & 1.45 & 84.85 & 0.22 \\
\hline Naukratis & BM 1888,0601.44 & Kneeling man & Dark & 1.15 & 0.53 & 1.17 & 78.50 & 0.30 \\
\hline Naukratis & BM 1888,0601.48 & Drummer & Dark & 0.83 & 1.03 & 4.61 & 72.11 & 0.40 \\
\hline Naukratis & BM 1886,0401.1331 & Ram & Dark & 0.52 & 0.09 & 0.73 & 92.01 & 0.19 \\
\hline Naukratis & BM 1886,1005.16 & Harpokrates & Dark & 0.59 & 0.30 & 1.99 & 84.76 & 0.83 \\
\hline Naukratis & BM 1886,0401.1330 & Musician & Dark & 1.31 & 1.13 & 5.21 & 60.20 & 1.15 \\
\hline Naukratis & AM AN 1896.1908.EA $5552 a$ & Bes head & Dark & 1.45 & 0.51 & 5.64 & 71.12 & 0.45 \\
\hline Naukratis & Louvre $\mathrm{E} 8056$ bis 14 & Scarab & Dark? & 0.19 & 0.11 & 0.36 & 97.44 & 0.68 \\
\hline Naukratis & BM 1886,0401.1616 & Scaraboid (circular plaque) & Yellow & 0.25 & 0.12 & 0.59 & 85.57 & 0.16 \\
\hline Naukratis & BM 1886,0401.1625 & Scarab & Yellow & 0.48 & 0.24 & 0.90 & 71.35 & 0.43 \\
\hline Naukratis & BM 1886.0401.1654 & Scarab & Yellow & 0.65 & 0.25 & 1.88 & 83.07 & 1.09 \\
\hline Naukratis & BM 1886,0401.1661 & Scarab & Yellow & 1.19 & 0.36 & 1.99 & 86.42 & 0.51 \\
\hline Naukratis & BM 1886,0401.1650 & Scarab & Yellow & 1.41 & 1.20 & 5.92 & 79.98 & 1.79 \\
\hline Naukratis & BM 1886,0401.1608 & Scaraboid (African) & Yellow & 1.57 & 0.62 & 2.51 & 76.33 & 3.92 \\
\hline Naukratis & BM 1886,0401.1676 & Scarab & Yellow & 1.85 & 0.79 & 2.98 & 78.63 & 0.46 \\
\hline Naukratis & Louvre $\mathrm{E} 8056$ bis 12 & Scarab & Yellow? & 0.56 & 0.80 & 1.04 & 86.67 & 1.51 \\
\hline Naukratis & Louvre E 8056 bis 5 & Scarab & Yellow? & 0.27 & 0.14 & 0.62 & 89.14 & 2.07 \\
\hline Kamiros & BM $1861,0425.20$ & Scaraboid (circular plaque) & Blue & 1.20 & 3.80 & 2.85 & 76.95 & 0.25 \\
\hline Kamiros & BM 1861,0425.21 & Scaraboid (circular plaque) & Blue & 1.15 & 0.88 & 1.73 & 89.68 & 0.16 \\
\hline Kamiros & Louvre E3899 & Scarab & Dark blue & 0.37 & 0.69 & 1.23 & 84.11 & 0.26 \\
\hline$?$ & BM 2013,5012.11 & Falcon (waster) & Blue & 0.29 & 0.12 & 1.05 & 94.86 & 0.22 \\
\hline Kamiros & BM 1861,0425.13 & Scarab & \begin{tabular}{|l} 
Blue-green \\
\end{tabular} & 1.20 & 1.11 & 1.93 & 77.76 & 0.26 \\
\hline Kamiros & BM 1861,0425.12 & Scarab & Blue-green & 1.11 & 1.17 & 2.32 & 78.53 & 0.27 \\
\hline Kamiros & BM 1861,1024.22 & Ram & Green & 0.69 & 0.71 & 3.06 & 87.02 & 0.64 \\
\hline Naukratis & BM 1886,0401.1645 & Couchant lion & Green & 1.50 & 0.60 & 2.31 & 74.25 & 1.21 \\
\hline Naukratis & BM 1888,0601.48 & Drummer & Blue-green & 0.64 & 0.65 & 3.18 & 85.87 & 0.37 \\
\hline Naukratis & BM 1888,0601.44 & Kneeling man & Green & 0.63 & 1.19 & 1.30 & 88.87 & 0.52 \\
\hline Naukratis & BM 1886,0401.1501 & Hedgehog aryballos & Green & 1.71 & 0.51 & 2.44 & 84.08 & 0.43 \\
\hline Naukratis & BM 1885,1101.30 & Pataikos & Green & 0.87 & 0.45 & 1.94 & 82.08 & 0.30 \\
\hline Naukratis & BM 1885,1101.58 & Bes head & Green & 0.31 & 0.41 & 1.91 & 88.05 & 0.68 \\
\hline Naukratis & BM 1885,1101.29 & New Year's flask & Green & 2.14 & 0.47 & 2.21 & 77.16 & 0.98 \\
\hline Naukratis & BM 1886,0401.1621 & Scarab & Green & 1.19 & 0.73 & 2.36 & 79.35 & 0.54 \\
\hline Naukratis & BM 1886,0401.1626 & Scarab & Green & 0.77 & 0.65 & 3.42 & 84.74 & 1.24 \\
\hline Naukratis & BM 1886,0401.1660 & Scarab & Green & 1.75 & 0.75 & 3.26 & 75.37 & 0.50 \\
\hline Naukratis & BM 1886,0401.1589 & New Year's flask & Green & 1.91 & 1.45 & 4.93 & 71.42 & 0.81 \\
\hline Naukratis & AM AN 1896.1908.EA $5552 \mathrm{a}$ & Bes head & Blue-green & 0.29 & 0.36 & 1.69 & 87.90 & 0.37 \\
\hline Naukratis & Louvre $\mathrm{E} 8056$ bis 3 & Scarab & Green & 0.57 & 0.18 & 1.24 & 93.41 & 0.69 \\
\hline Naukratis & Louvre $\mathrm{E} 8056$ bis 6 & Scarab & Green & 0.73 & 0.10 & 1.01 & 97.18 & 0.00 \\
\hline Naukratis & Louvre $\mathrm{E} 8056$ bis 13 & Scarab & Green & 0.24 & 0.10 & 0.14 & 93.67 & 2.30 \\
\hline Naukratis & Louvre E 8056 bis 11 & Scarab & Pale Green & 1.32 & 0.64 & 2.28 & 80.45 & 0.00 \\
\hline Naukratis & Louvre E 8056 bis 9 & Scarab & Green & 1.79 & 0.34 & 1.58 & 88.24 & 0.81 \\
\hline
\end{tabular}

Masson A., 2013-2015, "New Year's flasks", in Villing A., Bergeron M., Bourogiannis G., Johnston A., Leclère F., Masson A., Thomas R., Naukratis: Greeks in Egypt. British Museum Online Research Catalogue

(http://www.britishmuseum.org/research/ online_research_catalogues/ng/ naukratis_greeks_in_egypt/material_ culture_of_naukratis/new_years_flasks. aspx).

Newton R., Davison, S., 1989, Conservation of Glass, Oxford.

Pierrat-Bonnefois G., Bouquillon A., Coulié A., 2014, « La faïence dans le monde grec archaique, témoin priviligié de la complexité des échanges en Méditerrannée orientale ", in Coulié
A., Filimonos-Tsopotou M. (eds), Rhodes, une île grecque aux portes de l'Orient, Paris, p. 89-92.

Pierrat-Bonnefois G., BecqJ., Bouquillon A., Lehuédé P., 2015, « Faiences de Méditerranée orientale au musée du Louvre : questions et premières analyses ", in Kousoulis P., Lazaridis N. (eds), Proceedings of the Tenth International Congress of Egyptologists, University of the Aegean, Rhodes, 22-29 may 2008, Orientalia Lovaniensia Analecta series 241, Leuven.

Pollard A. M., Heron C., 2008, Archaeological Chemistry, Cambridge.
Salomon J., Dran J.-C., Guillou T., Moignard B., Pichon L., Walter P., Mathis F., 2008, "Ion-beam analysis for cultural heritage on the AGLAE facility: impact of PIXE/ RBS combination", Applied Physics A, 92, p. $43-50$

Shortland A. J., Tite M. S., Ewart I., 2006,

"Ancient exploration and use of cobalt alums from the western oases of Egypt", Archaeometry, 48(1), p. 153-168.

Strahan D. H., 1991, "Naturally deposited versus intentionally applied gypsum on archaeological materials from Harappa, Pakistan", Journal of Field Archaeology, 81, p. 527-530. 


\begin{tabular}{|c|c|c|c|c|c|c|c|c|c|c|c|c|c|c|c|c|c|c|}
\hline $\mathrm{SO}_{3}$ & $\mathrm{Cl}$ & $\mathrm{K}_{2} \mathrm{O}$ & $\mathrm{CaO}$ & $\mathrm{TiO}_{2}$ & $\mathrm{~V}_{2} \mathrm{O}_{3}$ & $\mathrm{MnO}$ & $\mathrm{Fe}_{2} \mathrm{O}_{3}$ & $\mathrm{CoO}$ & $\mathrm{NiO}$ & $\mathrm{CuO}$ & $\mathrm{ZnO}$ & $\mathrm{Rb}_{2} \mathrm{O}$ & $\mathrm{SrO}$ & $\mathrm{ZrO}_{2}$ & $\mathrm{SnO}_{2}$ & $\mathrm{Sb}_{2} \mathrm{O}_{5}$ & $\mathrm{BaO}$ & $\mathrm{PbO}$ \\
\hline $\begin{array}{l}1.10 \\
\end{array}$ & \begin{tabular}{c|}
0.39 \\
\end{tabular} & 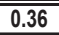 & $\begin{array}{c}0.50 \\
\end{array}$ & 0.05 & 0.01 & 0.01 & 0.20 & 0.00 & 0.00 & 0.37 & 0.03 & 0.00 & 0.00 & 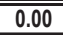 & 0.01 & 0.00 & 0.00 & 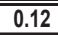 \\
\hline 0.82 & 0.38 & 0.57 & 0.53 & 0.06 & 0.00 & 0.01 & 0.26 & 0.00 & 0.00 & 0.28 & 0.02 & 0.00 & 0.00 & 0.00 & 0.01 & 0.00 & 0.00 & 0.07 \\
\hline 11.81 & 0.62 & 0.28 & 4.69 & 0.04 & 0.00 & 0.02 & 0.38 & 0.00 & 0.00 & 0.28 & 0.02 & 0.00 & 0.03 & 0.00 & 0.01 & 0.00 & 0.00 & 0.02 \\
\hline 8.47 & 0.31 & 0.46 & 7.02 & 0.10 & 0.00 & 0.06 & 0.80 & 0.01 & 0.01 & 0.10 & 0.01 & 0.00 & 0.04 & 0.00 & 0.00 & 0.00 & 0.02 & 0.02 \\
\hline 3.30 & 1.65 & 0.58 & 5.36 & 0.12 & 0.00 & 0.05 & 0.76 & 0.00 & 0.00 & 0.14 & 0.03 & 0.00 & 0.05 & 0.00 & 0.00 & 0.01 & 0.00 & 0.18 \\
\hline $\begin{array}{l}0.37 \\
\end{array}$ & 1.64 & 0.17 & 2.88 & 0.05 & 0.00 & 0.02 & 0.13 & 0.00 & 0.00 & 0.28 & 0.03 & 0.00 & 0.03 & 0.00 & 0.01 & 0.00 & 0.02 & 0.01 \\
\hline 5.35 & 1.40 & 0.74 & 8.61 & 0.06 & 0.01 & 0.08 & 0.74 & 0.00 & 0.00 & 0.10 & 0.07 & 0.00 & 0.04 & 0.00 & 0.01 & 0.00 & 0.05 & 0.02 \\
\hline 5.79 & 0.81 & 0.51 & 2.26 & 0.15 & 0.00 & 0.02 & 0.75 & 0.00 & 0.00 & 0.08 & 0.01 & 0.00 & 0.01 & 0.01 & 0.01 & 0.00 & 0.01 & 0.04 \\
\hline 1.76 & 1.71 & 0.66 & 4.73 & 0.27 & 0.00 & 0.03 & 1.16 & 0.00 & 0.00 & 0.24 & 0.02 & 0.00 & 0.03 & 0.00 & 0.00 & 0.01 & 0.02 & 0.60 \\
\hline 0.88 & 0.98 & 0.83 & 3.33 & 0.15 & 0.00 & 0.02 & 0.99 & 0.00 & 0.00 & 0.34 & 0.04 & 0.00 & 0.03 & 0.00 & 0.00 & 0.00 & 0.03 & 0.01 \\
\hline 0.81 & 0.69 & 0.18 & 1.25 & 0.04 & 0.00 & 1.81 & 2.19 & 0.03 & 0.02 & 0.55 & 0.02 & 0.00 & 0.01 & 0.00 & 0.00 & 0.03 & 0.01 & 0.20 \\
\hline 0.57 & 0.45 & 1.16 & 3.33 & 0.17 & 0.01 & 1.90 & 1.48 & 0.04 & 0.04 & 0.06 & 0.02 & 0.01 & 0.02 & 0.03 & 0.17 & 0.02 & 0.11 & 0.03 \\
\hline 2.41 & 0.77 & 0.97 & 3.74 & 0.37 & 0.01 & 2.82 & 3.59 & 0.05 & 0.12 & 1.36 & 0.03 & 0.01 & 0.05 & 0.02 & 0.01 & 0.00 & 0.04 & 0.10 \\
\hline 4.67 & 0.73 & 0.50 & 2.08 & 0.08 & 0.00 & 0.64 & 0.39 & 0.00 & 0.00 & 0.03 & 0.01 & 0.00 & 0.02 & 0.00 & 0.00 & 0.00 & 0.02 & 0.01 \\
\hline 7.35 & 0.18 & 0.66 & 3.91 & 0.07 & 0.01 & 2.99 & 0.59 & 0.00 & 0.01 & 0.08 & 0.02 & 0.00 & 0.04 & 0.00 & 0.00 & 0.01 & 0.05 & 0.03 \\
\hline 7.08 & 0.74 & 1.44 & 16.70 & 0.17 & 0.01 & 1.51 & 1.33 & 0.01 & 0.00 & 0.03 & 0.03 & 0.00 & 0.06 & 0.00 & 0.00 & 0.00 & 0.09 & 0.02 \\
\hline 2.92 & 1.04 & 0.45 & 1.79 & 0.14 & 0.00 & 5.22 & 0.55 & 0.00 & 0.01 & 0.16 & 0.01 & 0.00 & 0.02 & 0.13 & 0.00 & 0.00 & 0.01 & 0.06 \\
\hline 6.87 & 1.38 & 0.41 & 5.23 & 0.07 & 0.01 & 3.37 & 0.36 & 0.01 & 0.01 & 0.52 & 0.02 & 0.00 & 0.03 & 0.02 & 0.00 & 0.00 & 0.02 & 0.01 \\
\hline 11.31 & 0.37 & 0.77 & 4.96 & 0.16 & 0.01 & 2.04 & 1.00 & 0.01 & 0.01 & 0.17 & 0.02 & 0.00 & 0.02 & 0.01 & 0.00 & 0.00 & 0.10 & 0.06 \\
\hline 2.87 & 0.13 & 0.14 & 1.22 & 0.54 & 0.01 & 0.64 & 0.76 & 0.01 & 0.00 & 0.01 & 0.01 & 0.00 & 0.03 & 0.01 & 0.00 & 0.00 & 0.08 & 0.00 \\
\hline 2.78 & 1.50 & 0.64 & 2.71 & 0.14 & 0.01 & 1.42 & 1.56 & 0.01 & 0.00 & 0.15 & 0.01 & 0.00 & 0.03 & 0.01 & 0.01 & 0.00 & 0.21 & 0.29 \\
\hline 16.62 & 0.86 & 1.55 & 6.83 & 0.85 & 0.03 & 1.23 & 2.59 & 0.03 & 0.02 & 0.17 & 0.02 & 0.00 & 0.07 & 0.02 & 0.04 & 0.01 & 0.08 & 0.00 \\
\hline 8.86 & 0.83 & 1.25 & 3.55 & 0.27 & 0.02 & 1.56 & 2.13 & 0.01 & 0.01 & 1.51 & 0.01 & 0.00 & 0.03 & 0.03 & 0.50 & 0.01 & 0.11 & 0.14 \\
\hline 0.09 & 0.11 & 0.07 & 0.39 & 0.03 & 0.00 & 0.00 & 0.44 & 0.00 & 0.00 & 0.02 & 0.00 & 0.00 & 0.01 & 0.00 & 0.01 & 0.01 & 0.00 & 0.02 \\
\hline 0.00 & 0.51 & 0.16 & 2.93 & 0.10 & 0.00 & 0.01 & 0.34 & 0.00 & 0.01 & 0.19 & 0.01 & 0.00 & 0.02 & 0.02 & 0.00 & 1.88 & 0.00 & 7.12 \\
\hline 2.12 & 0.97 & 0.35 & 3.61 & 0.21 & 0.00 & 0.01 & 0.39 & 0.00 & 0.00 & 0.30 & 0.01 & 0.00 & 0.03 & 0.02 & 0.30 & 10.35 & 0.00 & 7.91 \\
\hline 1.17 & 0.65 & 0.29 & 3.30 & 0.08 & 0.00 & 0.02 & 0.48 & 0.00 & 0.00 & 0.13 & 0.01 & 0.00 & 0.02 & 0.00 & 0.02 & 0.98 & 0.02 & 5.88 \\
\hline 3.34 & 0.81 & 0.47 & 2.19 & 0.07 & 0.00 & 0.00 & 0.71 & 0.02 & 0.01 & 0.11 & 0.01 & 0.00 & 0.03 & 0.02 & 0.06 & 0.71 & 0.00 & 0.96 \\
\hline 1.27 & 0.96 & 1.65 & 2.46 & 0.11 & 0.01 & 0.02 & 0.88 & 0.00 & 0.00 & 0.32 & 0.01 & 0.00 & 0.02 & 0.01 & 0.01 & 0.72 & 0.00 & 1.25 \\
\hline 1.82 & 1.51 & 0.71 & 3.61 & 0.17 & 0.01 & 0.02 & 3.76 & 0.01 & 0.00 & 0.05 & 0.01 & 0.00 & 0.04 & 0.01 & 0.03 & 1.28 & 0.02 & 1.98 \\
\hline 4.97 & 1.83 & 0.51 & 4.71 & 0.16 & 0.00 & 0.02 & $\begin{array}{l}0.72 \\
\end{array}$ & 0.00 & 0.00 & 0.60 & 0.01 & 0.00 & 0.02 & 0.01 & 0.01 & 0.55 & 0.01 & 1.16 \\
\hline 0.31 & 0.34 & 0.22 & 2.52 & 1.38 & 0.00 & 0.05 & 1.20 & 0.01 & 0.00 & 0.19 & 0.00 & 0.00 & 0.02 & 0.12 & 0.82 & 0.86 & 0.02 & 1.35 \\
\hline 0.30 & 0.36 & 0.20 & 1.85 & 0.33 & 0.00 & 0.01 & 1.10 & 0.00 & 0.00 & 0.05 & 0.00 & 0.00 & 0.03 & 0.01 & 0.20 & 0.70 & 0.00 & 2.61 \\
\hline 4.12 & 1.23 & 0.70 & 4.18 & 0.09 & 0.00 & 0.07 & 1.20 & 0.28 & 0.11 & 2.81 & 0.02 & 0.00 & 0.02 & 0.03 & 0.03 & 0.01 & 0.00 & 0.06 \\
\hline 1.72 & 0.43 & 0.19 & 1.30 & 0.02 & 0.00 & 0.02 & 0.61 & 0.07 & 0.01 & 1.72 & 0.03 & 0.00 & 0.01 & 0.00 & 0.10 & 0.00 & 0.02 & 0.14 \\
\hline 0.73 & 0.63 & 0.25 & 2.19 & 0.03 & 0.00 & 0.08 & 0.59 & 0.11 & 0.02 & 8.12 & 0.03 & 0.00 & 0.01 & 0.00 & 0.01 & 0.01 & 0.01 & 0.51 \\
\hline 1.51 & 0.04 & 0.17 & 0.78 & 0.02 & 0.00 & 0.01 & 0.53 & 0.10 & 0.03 & 0.20 & 0.01 & 0.00 & 0.00 & 0.00 & 0.05 & 0.00 & 0.01 & 0.01 \\
\hline 2.22 & 0.62 & 0.51 & 3.49 & 0.06 & 0.01 & 0.45 & 1.27 & 0.02 & 0.02 & 5.64 & 0.02 & 0.00 & 0.03 & 0.00 & 0.01 & 0.80 & 0.00 & 2.58 \\
\hline 2.15 & 1.02 & 0.62 & 3.99 & 0.08 & 0.01 & 0.02 & 0.75 & 0.01 & 0.01 & 4.11 & 0.04 & 0.00 & 0.03 & 0.00 & 0.00 & 0.71 & 0.03 & 3.03 \\
\hline 3.36 & 0.30 & 0.34 & 2.34 & 0.15 & 0.00 & 0.02 & 0.73 & 0.00 & 0.00 & 0.47 & 0.01 & 0.00 & 0.02 & 0.06 & 0.00 & 0.00 & 0.02 & 0.05 \\
\hline 4.94 & 1.45 & 0.95 & 5.35 & 0.10 & 0.02 & 0.06 & 6.49 & 0.00 & 0.00 & 0.24 & 0.04 & 0.00 & 0.25 & 0.00 & 0.00 & 0.01 & 0.02 & 0.20 \\
\hline 2.60 & 1.10 & 0.74 & 3.15 & 0.10 & 0.00 & 0.04 & 0.64 & 0.00 & 0.01 & 0.61 & 0.04 & 0.00 & 0.01 & 0.06 & 0.00 & 0.00 & 0.03 & 0.13 \\
\hline 0.79 & 1.01 & 0.41 & 4.24 & 0.10 & 0.00 & 0.01 & 0.41 & 0.00 & 0.00 & 0.44 & 0.02 & 0.00 & 0.03 & 0.00 & 0.00 & 0.00 & 0.00 & 0.01 \\
\hline 5.55 & 0.81 & 0.44 & 2.56 & 0.12 & 0.00 & 0.06 & 0.59 & 0.00 & 0.00 & 0.43 & 0.01 & 0.00 & 0.01 & 0.01 & 0.00 & 0.00 & 0.01 & 0.23 \\
\hline 6.90 & 1.13 & 0.26 & 2.28 & 0.06 & 0.00 & 0.01 & 0.36 & 0.00 & 0.00 & 2.84 & 0.01 & 0.00 & 0.02 & 0.00 & 0.05 & 0.00 & 0.01 & 0.42 \\
\hline 1.18 & 2.17 & 0.73 & 0.87 & 0.04 & 0.00 & 0.01 & 0.69 & 0.01 & 0.00 & 2.45 & 0.01 & 0.00 & 0.01 & 0.00 & 0.01 & 0.00 & 0.01 & 0.45 \\
\hline 5.49 & 0.62 & 0.91 & 2.57 & 0.14 & 0.00 & 0.33 & 2.14 & 0.04 & 0.02 & 1.76 & 0.02 & 0.00 & 0.03 & 0.00 & 2.09 & 0.04 & 0.02 & 0.80 \\
\hline 5.18 & 1.24 & 0.52 & 5.61 & 0.07 & 0.00 & 0.01 & 0.53 & 0.00 & 0.00 & 0.86 & 0.01 & 0.00 & 0.03 & 0.02 & 0.00 & 0.24 & 0.02 & 1.47 \\
\hline 2.17 & 0.63 & 0.44 & 2.11 & 0.08 & 0.00 & 0.01 & 0.66 & 0.00 & 0.00 & 0.97 & 0.01 & 0.00 & 0.01 & 0.00 & 0.08 & 0.40 & 0.00 & 1.60 \\
\hline 4.72 & 1.82 & 1.03 & 5.89 & 0.09 & 0.01 & 0.03 & 0.70 & 0.00 & 0.00 & 1.49 & 0.01 & 0.00 & 0.04 & 0.01 & 0.10 & 0.51 & 0.00 & 1.89 \\
\hline 5.79 & 2.55 & 0.56 & 5.30 & 0.29 & 0.01 & 0.10 & 1.47 & 0.00 & 0.00 & 0.74 & 0.00 & 0.00 & 0.02 & 0.01 & 0.16 & 0.56 & 0.01 & 1.90 \\
\hline 3.93 & 0.65 & 0.34 & 1.86 & 0.07 & 0.00 & 0.03 & 0.23 & 0.00 & 0.00 & 1.99 & 0.01 & 0.00 & 0.02 & 0.02 & 0.05 & 0.00 & 0.01 & 0.16 \\
\hline 0.21 & 0.21 & 0.32 & 0.62 & 0.05 & 0.00 & 0.07 & 1.65 & 0.02 & 0.00 & 0.21 & 0.02 & 0.00 & 0.01 & 0.00 & 0.29 & 0.00 & 0.03 & 0.19 \\
\hline 0.05 & 0.37 & 0.20 & 0.14 & 0.01 & 0.00 & 0.01 & 0.16 & 0.01 & 0.00 & 0.01 & 0.00 & 0.00 & 0.00 & 0.00 & 0.00 & 0.00 & 0.00 & 0.00 \\
\hline 0.46 & 0.18 & 0.24 & 0.99 & 0.04 & 0.00 & 0.00 & 1.38 & 0.01 & 0.00 & 0.04 & 0.00 & 0.00 & 0.02 & 0.00 & 0.15 & 0.00 & 0.00 & 0.02 \\
\hline 0.60 & 2.08 & 0.59 & 3.32 & 0.04 & 0.00 & 0.01 & 0.38 & 0.00 & 0.00 & 1.16 & 0.04 & 0.00 & 0.03 & 0.00 & 0.00 & 1.18 & 0.03 & 5.83 \\
\hline 0.67 & 1.17 & 0.48 & 2.70 & 0.06 & 0.00 & 0.02 & 0.28 & 0.00 & 0.00 & 0.25 & 0.01 & 0.00 & 0.12 & 0.00 & 0.01 & 0.42 & 0.01 & 1.03 \\
\hline
\end{tabular}

Tite M. S., Freestone I. C., Bimson M., 1987, "The scientific examination of PreHellenistic faience from Rhodes", in Bimson M., Freestone I. C. (eds), Early Vitreous Materials, BM Occasional Paper 56, London, p. 127-130.

Tite M. S., Freestone I. C., Bimson M., 1983, "Egyptian faience: An investigation of the methods of production", Archaeometry 25, 17-27.

Tite M. S., Shortland A. J., 2003, "Production technology for copper and cobalt-blue vitreous materials from the New Kingdom site of Amarna - a reappraisal", Archaeometry 45 p. 285-312.

Tite M. S., Maniatis Y., Kavoussanaki D., Panagiotaki M., Shortland A. J., Kirk S. F., 2009, "Colour in Minoan faience", Journal of Archaeological Science 36, p. $370-378$

Webb V., 2013-2015a, "Archaic mixed style faience figures", in Villing A., Bergeron M., Bourogiannis G., Johnston A., Leclère F., Masson A., Thomas R., Naukratis: Greeks in Egypt. British Museum Online Research Catalogue.

(http://www.britishmuseum.org/research/ online_research_catalogues/ng/ naukratis_greeks_in_egypt/material_ culture_of_naukratis/mixed_style_ faience_figures.aspx).

Webb V., 2013-2015b, "Archaic mixed style faience vessels", in Villing A., Bergeron M., Bourogiannis G., Johnston A., Leclère F.,

Masson A., Thomas R., Naukratis: Greeks in Egypt. British Museum Online Research Catalogue. (http://www.britishmuseum. org/research/online_research_ catalogues/ng/naukratis_greeks_in_ egypt/material_culture_of_naukratis/ mixed_style_faience_vessels.aspx). 